Western University

Scholarship@Western

Education Publications

Education Faculty

2011

\title{
The Postmodern Curriculum: Making Space for Historically and Politically Situated Understandings
}

Veronica Pacini-Ketchabaw

Western University, vpacinik@uwo.ca

Alan Pence

University of Victoria

Follow this and additional works at: https://ir.lib.uwo.ca/edupub

Part of the Early Childhood Education Commons

Citation of this paper:

Pacini-Ketchabaw, Veronica and Pence, Alan, "The Postmodern Curriculum: Making Space for Historically and Politically Situated Understandings" (2011). Education Publications. 18.

https://ir.lib.uwo.ca/edupub/18 


\title{
The postmodern curriculum: \\ Making space for historically and politically situated understandings
}

\author{
Veronica Pacini-Ketchabaw \\ Alan Pence \\ University of Victoria, Canada
}

BY ENGAGING POSTSTRUCTURAL, postmodern and indigenous lenses, this article explores challenges associated with recently developed 'postmodern' early childhood education curricula. The authors propose that curricula should not be seen as neutral, but rather as historically and politically situated documents that require dynamic and critical engagements from educators. We situate our analysis within Canada.

\section{Curricula/frameworks in Canadian early childhood education}

Over the past five years, Canadian provincia governments have been actively involved in designing and implementing curricula documents or frameworks for practice as a way to achieve 'quality' in early childhood services. While this approach to 'quality' has been common in various Western countries le.g. Sweden, Italy, Spain, New Zealand-Bennett, 2004; Moss, 2005), Canada has only recently engaged in institutionalising pedagogies. Part of this growing interest has been the result of international calls for quality early childhood education (OECD, 2003). Canada has been criticised for its mediocre systems and lack of commitment in supporting the care and education of young children (OECD, 2003).

In response to this criticism, several provincial governments have developed a curriculum or framework to enhance quality (e.g. Best Start Expert Panel on Early Learning, 2007; Government of British Columbia, 2008; Early Childhood Research and Development Team, 2007; Saskatchewan Ministry of Education, 2008). These curricula or frameworks address, broadly speaking, pedagogical issues to be considered, and in some cases followed, by early childhood educators and other practitioners working in early childhood services.
They range from developmental standards for assessing children's normal development to general guidelines and frameworks for early childhood educators to reflect upon as they engage with children and families.

An interesting trend in the recently published Canadian curricula/frameworks is a move away from long-debated guidelines such as Developmentally Appropriate Practices (DAP) which have dominated the thinking within early childhood education (ECE) for many decades in North America (Cannella, 1997; Dahlberg, Moss \& Pence, 1999). Responding to the critiques of the DAP guidelines, some governments (e.g. British Columbia, New Brunswick and Saskatchewan) have demonstrated an interest in embedding aspects of postmodern practices and theories (Early Childhood Research and Development Team, 2007; Government of British Columbia, 2008; Saskatchewan Ministry of Education, 2008). These documents speak of children's identities as complex, multiple, and situated within historical, cultural and social contexts. They move away from standardised testing, acknowledge cultural and linguistic diversity (typically through the inclusion of indigenous issues), and propose tools such as pedagogical documentation and learning stories as preferred methods for engaging in practices that value depth and context. In this article, we loosely refer to these curricula/frameworks as 'postmodern'. 
This article considers some of the challenges that postmodern curricula/frameworks pose. The first part of the article briefly describes postmodern approaches to early childhood from the perspective of the 'discourse of meaning-making'. The second part situates postmodern curricula/frameworks within the context of the 'discourse of meaning-making'noting some general challenges and/or 'ideas to consider'. Our intent is not to discuss whether these curricula/frameworks are good or bad, but rather what opportunities they present, what limitations they have, and what needs to be considered as educators engage with curricula/frameworks that embrace broad strokes of the postmodern.

\section{The discourse of meaning-making: Moving beyond modernity}

Some recently created curricula/frameworks have embraced some of the critiques of the instrumentation approach to 'quality' that has dominated the early childhood education field in Canada for a long time. Instrumentation and reductionist approaches to quality have been problematised as a too narrow approach to the diverse ways of being and becoming (Dahlberg et al., 1999). Such approaches are based on a modernist belief in a singular definition of 'best' - that through a scientific and experimental approach a transcendent 'truth' will be revealed. While the physical sciences (used as the model for social science research) have long since given up on assumptions of 'objectivity' and sense of instrumental 'neutrality', some social sciences (child development among them) have maintained that position-even bowing to the fact that such 'truths' fail their own scientific criteria for the claims of generalisability put forward. For example, how could 'universals' in child development be based on research that covers, at best, five per cent of the world's child population (Arnett, 2008; Pence \& Hix-Small, 2009)? Clearly, there is much more to quality than 'quality instruments' and much more to child development than US-based norms. Childhood and the experiences of childhood are cultural and contextually constructed and situated. What constitutes a 'good childhood', as well as a 'good adulthood', varies enormously, and to expect a theory, an instrument, or a set of values to adequately represent that diversity is not possible. Contextualised meaning-making is central to an adequate understanding of children, children's programs and policies.

Given these critiques, the construct of 'quality' has been re-imagined and alternative perspectives have been posited by scholars in the field. Dahlberg and colleagues (1999) have suggested a move from the discourse of 'quality' to the discourse of meaning-making. The discourse of meaning-making acknowledges the different ways of seeing and being in the world and early childhood education institutions. The two discourses, quality and meaning-making, are situated within different philosophical traditions and embed different values and assumptions. Here Dahlberg and colleagues (1999) provide a description of the discourse of meaning-making:

The discourse of meaning making speaks first and foremost about constructing and deepening understanding of the early childhood institution and its projects, in particular the pedagogical work - to make meaning of what is going on. From constructing these understandings, people may choose to continue by attempting to make judgments about the work, a process involving the application of values to understanding to make a judgment of value. Finally, people may further choose to see some agreement with others about these judgments-to struggle to agree, to some extent, about what is going on and its value (p. 106).

With the discourse of meaning-making, alternative pedagogies emerge-pedagogies that allow children and educators to co-construct knowledge and to resist dominant understandings that have become normalised. These new forms of pedagogies have been an important aspect of some of the recently created curricula/frameworks in Canada. For example, the British Columbia Early Learning Framework (Government of British Columbia, 2008) refers to the notion that there is not one approach to learning or that learning is not necessarily unilateral. The framework values the flexible child and the flexible educator who are always shifting positions within the multiple contexts they inhabit:

Young children's powerful drive to learn is inextricably linked to their emerging identities as members of social, cultural, linguistic, and geographic communities. Children's curiosity inspires them to interact with other people, and with things and places in their environments, virtually from birth. It is in the dance between children and other children and adults that language and culture are created and recreated from generation to generation. In this dance, children are sometimes the leaders, and adults the followers, and vice versa. Adults' responses to children's activities-whether they respond, the appropriateness of their responses, and the creativity of their responses-affect young children's early learning capacities and their growing sense of themselves as members of their communities. These interactions also give adults the opportunity to learn, grow, and change, and to cultivate a disposition that welcomes children's contributions (p. 10).

In this article we are interested in the relationship between postmodern curricula and the discourse of 
meaning-making. How might postmodern curricula/ frameworks be interpreted/thought of when working within postmodern paradigms? Several challenges arise when postmodern curricula/frameworks are seen through the lenses of the discourse of meaning-making. In the next section, we use poststructural, feminist and postcolonial theories to note some of these challenges.

\section{Curriculum and the discourse of meaning- making: Working within postmodernity}

First, postmodern curricula/frameworks cannot be thought of as innocent tools that provide the solution to the complex landscape of early childhood education. Such a position would involve returning to the singularity of modernist ways of thinking. In Beyond Quality, Dahlberg and colleagues (1999) suggest we should not 'fool ourselves about what frameworks of normalization [e.g. discourse of 'quality'] are or what they can do' (p. 116). They say: 'Let us recognize their limitations and dangers, their assumptions and values. Let them not be at the expense of ignoring other ways of thinking about and making sense of early childhood institutions and the work they do' (p. 116). We believe that similar concerns need to be considered when engaging with 'postmodern' curricula/frameworks.

At the same time, we do not suggest that curricula/ frameworks are bad and should be forgotten. Rather, we suggest re-imagining the ways educators engage with their meanings, their implications, and their uses. In other words, it is important to continue to engage with the discourse of meaning-making when working with postmodern curricula/frameworks. These ideas were noted by Pinar, Reynolds, Slattery and Taubman (2000) almost a decade ago:

The field [of curriculum studies] no longer sees the problems of curriculum and teaching as 'technical' problems, that is problems of 'how to'. The contemporary field regards the problems of curriculum and teaching as 'why' problems. Such a view requires that we understand what was before considered only something to be solved. Now, the contemporary field is hardly against solving problems, but the view today is that solutions to problems do not just require kneejerk, commonsensical responses, but careful, thoughtful, disciplined understandings (p. 8).

The words speak about engagements with curriculum, about acknowledging and struggling with its complexities, about deliberation, and about the necessity of viewing curriculum as a provocation to ask difficult questions. Curriculum cannot become what educators follow, a single direction that educators need to take, that which early childhood education services need to overcome or to manage or to conquer (Looney,
2001). Curriculum can instead become an opportunity for resisting, for making meaning, and furthermore for searching for other (invisible, out-of-sight) meanings. Researchers and educators are not blindly to follow these curricula/frameworks because they embrace aspects of the postmodern, but can instead engage meaningfully in contesting and resisting them by asking questions that will bring practice to 'other' spaces. Again, this does not mean that these documents are to be dismissed, rather that they need to be used 'differently'-perhaps through the lenses of the meaning-making discourse.

This re-imagination involves understanding postmodern curricula/frameworks as being historically, socially and politically situated within relations of power (not outside of them), as social constructions (not Truths). Dussel, Tiramonti and Birgin (2000) suggested thinking of curricula/frameworks as part of 'new maps of relations between the centre and the periphery of the educational system' (p. 537). The questions to ask are: What new cartographies of power do postmodern curricula/frameworks establish? How are young children and educators re-positioned and re-shaped within these new cartographies? What new languages are created and for what purposes?

The precise idea of curriculum is also to be situated within its own historical context. Curricula emerged as a 'grand narrative' of the West, as part of the technical-rational or factory model to construct efficient and effective societies (Pinar et al., 2000). In the same way that the discourse of quality is understood 'in relation to the modernist search for order and certainty' (Dahlberg et al., p. 89), Lenz Taguchi (2008) suggests understanding curricula/frameworks as part of administrative and regulatory societal practiceseven when those documents attempt to embrace postmodernity.

As mentioned above, the postmodern curriculum/ framework stresses diversity, and a particularly valuable lens for such diversity has been Indigenous perspectives. Because curricula/frameworks are always situated within social, political and historical contexts, they are also to be examined in relation to colonial histories (Weenie, 2008). In Canada, as in other countries, curricula and frameworks for practice have acted as tools through which Indigenous communities' languages, ways of being and doing, and cultural knowledge have been marginalised and often silenced. Postcolonial and Indigenous theories have made important contributions to the understanding of curriculum. These insights are to be considered within the context of early childhood education.

The landscape of Aboriginal curriculum involves the colonial history, worldviews, philosophies, languages, cultures, stories, songs, literature, art,

6 Australasian Journal of Early Childhood 
spirituality, ceremonies and ethos of Aboriginal people. These are the 'things' or objects that make up our embodied ways of knowing. They form a body of knowledge that represent the order of things in the worlds we live and work in. They constitute an Indigenous model of curriculum that can no longer be disregarded. They cannot be mere add-ons or supplementary pieces but the core components of Aboriginal curriculum. Curricular theorizing from this standpoint needs to be 'an act of imagination that is a patterned integration of our remembered past, perceived present, and our anticipated future' (Weenie, 2008, p. 551-2).

The treatment of Indigenous issues in Canadian ECE postmodern curricula/frameworks is often through side-bars. As educators actively engage with the documents, they are, as Weenie (2008) suggests in her quote, to destabilise these approaches to the treatment of Aboriginal issues in curriculum documents and engage in deeper contestations that move educational communities beyond mere acknowledgement and inclusion toward decolonisation.

Finally, the re-imagination of curriculum requires thinking critically about a key element of the postmodern curricula/frameworks: reflexive practice. Poststructural and feminist scholars have warned us of the dangers of reflexivity as a way of engaging in a process of searching for educators' inner feelings (Burman, 2009; MacNaughton, 2003). These types of reflexive practices, although presented as a counterpart to technicisation and instrumentalisation, have become part of neo-liberal strategies of government. Fendler (2003) notes that 'some reflective practices may simply be exercises in reconfirming, justifying, or rationalizing preconceived ideas' (p. 16). These critiques suggest that, when engaged in reflective practice, educators perhaps need to remember that the goal is not to find an answer to their everyday practices, but rather that reflective practice can be used 'to tell a story that is just that: a story, a situated, partial version; not the whole story. Or even to tell lots of stories' (Burman, 2009, p. 148).

Thompson (2010), writing about her own processes with critical reflective practice while working with the British Columbia Early Learning Framework (Government of British Columbia, 2008), notes her own struggles with the process:

I gradually became aware that I was engaged in a process of self (or perhaps centre) congratulations. In the past I had been reluctant to use accepted 'quality measurement' tools ... to evaluate the practice in our centre as it seemed obvious that we would score high, which I believed would lead to complacency. Yet I had quickly become complacent (and perhaps even smug) using a tool explicitly designed for critical reflection! The awareness that I had easily slid into reconfirming what already thought-in spite of understanding myself as practicing critical reflection for the purpose of improving practice-shocked me ... (p. 88).

Reflective practice can become risky business if the historically, socially and politically implicated discourses are not deconstructed. Critical reflection cannot be about making the self visible, but about re-imagining new subjectivities in relation to different contexts.

\section{Possibilities}

We welcome these recently developed curricula/ frameworks that attempt to respond to the critiques of modernity for the possibilities they present in comparison to more narrow policies and discourses. We are, however, cautious about how they are understood, how they are used, and what messages are taken from them.

Like Pinar and colleagues (2000), we invite the reader to think of curriculum as 'intensely historical, political, racial, gendered, phenomenological, autobiographical, aesthetic, theological, and international' (p. 847). Postmodern curricula/frameworks in early childhood education can become 'the site on which the generations struggle to define themselves and the world' through 'an extraordinarily complicated conversation' (Pinar et al., 2000, p. 848). Pinar and his colleagues note:

Once we shift the point of the curriculum away from the institutional, economic, and political goals of others, once we 'take it back' for ourselves, we realize we must explore curriculum as a historical event itself. That is, as soon as we take hold of the curriculum as an opportunity for ourselves, as citizens, as persons, we realize that curriculum changes as we reflect on it, engage in its study, and act in response to it, toward the realization of our ideals and dreams. Curriculum ceases to be a thing, and it is more than a process. It becomes a verb, an action, a social practice, a private meaning, and a public hope. Curriculum is not just the site of our labor, it becomes the product of our labor, changing as we are changed by it (p. 848).

Postmodern curricula/frameworks open spaces for educators to engage in dialogue with practice in 'careful, thoughtful, and disciplined' ways and create new possibilities for early childhood education curriculum itself. Postmodern curricula/frameworks cannot be used as 'how to' guides but as documents that embrace the idea of curriculum as a dynamic and fluid encounter. They are not technical formulas requiring the deduction of objectives or goals. They provide general principles and criteria that require fertile action-in other words these principles and criteria are to be translated and re-created in specific 
local contexts. This approach requires that educators rethink the institution and the educational practices which are always subject to revision, evaluation and readjustments. Revisions and re-adjustments can be done in relation to dynamic social, political and pedagogical changes that require constant analysis and re-thinking. Key to the argument made in this article is that there is not a 'best' curriculum, but a possible curriculum in permanent evaluation and change. Instead of using curricula/frameworks as technologies of social control, educators can use these documents for the production of new worlds or new realities for themselves and the children they work with.

\section{References}

Arnett, J. J. (2008). The neglected 95\%: Why American psychology needs to become less American. American Psychologist, 63(7), 602-614.

Bennett, J. (2004). Starting strong curricula and pedagogies in early childhood education and care: Five curriculum outlines. OECD Directorate for Education. Retrieved 6 April, 2009 from www.oecd.org/dataoecd/23/36/31672150.pdf.

Best Start Expert Panel on Early Learning (2007). Early learning for every child today: A framework for Ontario early childhood settings. Retrieved 6 April, 2009 from www.gov.on.ca/children/ graphics/263264.pdf.

Burman, E. (2009). Beyond 'emotional literacy' in feminist and educational research. British Educational Research Journal, 35(1),137-155.

Cannella, G. S. (1997). Deconstructing early childhood education social justice and revolution. New York: P. Lang.

Dahlberg, G., Moss, P., \& Pence, A.R. (1999). Beyond quality in early childhood education and care: Postmodern perspectives. London: Falmer Press.

Dussel, I., Tiramonti, G., \& Birgin, A. (2000). Towards a new cartography of curriculum reform: reflections on educational decentralization in Argentina. Journal of Curriculum Studies, 32(4), 537-559.

Early Childhood Research and Development Team (2007). Early learning and child care: English curriculum framework for New Brunswick. Fredericton, New Brunswick: Family and Community Services.

Fendler, L. (2003). Teacher reflection in a hall of mirrors: Historical influences and political reverberations. Educational Researcher, 32(3), 16-25.

Government of British Columbia (2008). British Columbia early learning framework. Victoria, BC: Ministry of Education, Ministry of Health, Ministry of Children and Family Development and British Columbia Early Learning Advisory Group.

Lenz Taguchi, H. (2008). An 'Ethics of resistance': Challenges taken-for-granted ideas in Swedish early childhood education. International Journal of Educational Research, 47(5), 270-282.

Looney, A. (2001). Curriculum as policy: Some implications of contemporary policy studies for the analysis of curriculum policy, with particular reference to post-primary curriculum policy in the Republic of Ireland. Curriculum Journal, 12(2), 149-162.
MacNaughton, G. (2003). Shaping early childhood: Learners, curriculum and contexts. Maidenhead: Open University Press.

Moss, P. (2005). Curriculum and assessment in the early years [Special issue]. Children in Europe, 9.

Organisation for Economic Cooperation and Development (OECD) (2003). Early Childhood Education and Care Policy: Canada Country Note. OECD Directorate for Education. Retrieved 22 June, 2006, from http://www.oecd.org/ dataoecd/42/34/33850725.pdf.

Pence, A., \& Hix-Small, H. (2009). Global children in the shadow of the global child. International Critical Childhood Policy Studies Journal, 2(1), 75-91.

Pinar, W. F., Reynolds, W. M., Slattery, P., \& Taubman, P. M. (2000). Understanding curriculum: An introduction to the study of historical and contemporary curriculum discourses. New York: Peter Lang.

Saskatchewan Ministry of Education (2008). Play and exploration: Early learning program guide. Saskatoon, Saskatchewan: Early Learning and Child Care Branch Ministry of Education

Thompson, D. (2010). A story to unsettle assumptions about critical reflection in practice. In V. Pacini-Ketchabaw (Ed), Flows, rhythms and intensities of early childhood education curriculum (pp. 77-94). NY: PeterLang.

Weenie, A. (2008). Curricular Theorizing From the Periphery. Curriculum Inquiry, 38(5), 545-557.

8 Australasian Journal of Early Childhood 